\title{
Mycorrhizal Inoculation Differentially Affects Grapevine's Performance in Copper Contaminated and Non-contaminated Soils
}

\author{
Amaia Nogales ${ }^{1 *}$, Erika S. Santos ${ }^{1}$, Maria Manuela Abreu ${ }^{1}$, Diego Arán ${ }^{2,3}$, \\ Gonçalo Victorino ${ }^{1}$, Helena Sofia Pereira ${ }^{1}$, Carlos M. Lopes ${ }^{1}$ and Wanda Viegas ${ }^{1}$ \\ 1 Linking Landscape, Environment, Agriculture and Food (LEAF), Instituto Superior de Agronomia (ISA), Universidade de \\ Lisboa, Lisbon, Portugal, ${ }^{2}$ Instituto de Investigaciones Tecnológicas, University of Santiago de Compostela, Santiago de \\ Compostela, Spain, ${ }^{3}$ Improyen Consulting, Santa Comba, Spain
}

OPEN ACCESS

Edited by: Andrea Genre,

Università degli Studi di Torino, Italy

Reviewed by:

Nieves Goicoechea, University of Navarra, Spain

Walter Chitarra,

Council for Agricultural and Economics Research, Italy

*Correspondence: Amaia Nogales anogales@isa.ulisboa.pt

Specialty section: This article was submitted to Plant Microbe Interactions, a section of the journal Frontiers in Plant Science

Received: 21 September 2018 Accepted: 07 December 2018

Published: 25 January 2019

Citation:

Nogales A, Santos ES, Abreu MM, Arán D, Victorino G, Pereira HS,

Lopes CM and Viegas W (2019) Mycorrhizal Inoculation Differentially Affects Grapevine's Performance in

Copper Contaminated and Non-contaminated Soils.

Front. Plant Sci. 9:1906. doi: $10.3389 /$ fpls.2018.01906
Plant inoculation with arbuscular mycorrhizal fungi (AMF) is increasingly employed to enhance productivity and sustainability in agricultural ecosystems. In the present study, the potential benefits of AMF inoculation on young grapevines replanted in pots containing vineyard soil with high $\mathrm{Cu}$ concentration were evaluated. For this purpose, one-year-old cv. Touriga Nacional grapevines grafted onto 1103P rootstocks were further inoculated with Rhizoglomus irregulare or Funneliformis mosseae, or left non-inoculated, and maintained in a sterilized substrate under greenhouse conditions for three months. After this time, half of the plants were transplanted to containers filled with an Arenosol from a vineyard which had been artificially contaminated or not with $300 \mathrm{mg} \mathrm{kg}^{-1}$ of $\mathrm{Cu}$. At the end of the growing season, soil nutrient concentration, soil dehydrogenase activity and mycorrhizal colonization rate were analyzed. Grapevine performance was assessed by measuring several vegetative growth and physiological parameters as well as nutrient concentrations in leaves and roots. In the non-contaminated soil, $R$. irregulare- and F. mosseae-inoculated plants had significantly greater root biomass than the non-inoculated ones. However, the opposite effect was observed in the Cu-contaminated soil, where non-inoculated plants performed better regarding shoot and root development. Concerning nutrient levels, an increase in $\mathrm{Cu}, \mathrm{Mg}$ and $\mathrm{Mn}$ concentrations was observed in the roots of plants growing in the contaminated soil, although only $\mathrm{Mn}$ was translocated to leaves. This led to a large increase in leaf $\mathrm{Mn}$ concentrations, which was significantly higher in noninoculated and F. mosseae- inoculated plants than in the R. irregulare- inoculated ones. Copper contamination induced a general decrease in leaf N, P and Fe concentrations as well as chlorosis symptoms. The largest decrease in $N$ and $P$ was observed in F. mosseae- inoculated plants, with 73 and $31.2 \%$, respectively. However, these plants were the ones with the least decrease in Fe concentration (10\% vs. almost $30 \%$ in the other two inoculation treatments). In conclusion, this study indicates that soil $\mathrm{Cu}$ levels can modify the outcome of AMF inoculations in young grapevines, disclosing new AMF-plant associations potentially relevant in vineyards with a tradition of Cu-based fungicide application.

Keywords: arbuscular mycorrhizal fungi, symbiosis, Vitis vinifera L. cv. touriga nacional, copper, soil contamination, manganese toxicity 


\section{INTRODUCTION}

Copper is an essential micronutrient for most organisms. In plants, it has important functions in key physiological processes, and is usually taken up by root systems in the form of divalent cations or $\mathrm{Cu}$ chelates from the available fraction of soils. Relevant plant processes which require $\mathrm{Cu}$ include photosynthetic electron transport, mitochondrial respiration, oxidative stress responses, cell wall metabolism and hormone signaling (Marschner, 1995; Raven et al., 1999; Kabata-Pendias, 2010; Miotto et al., 2014). Copper is also a structural element in regulatory proteins, acting as a cofactor in many metalloproteins (Yruela, 2009). However, it can be highly toxic for plants and soil (micro)organisms at high concentrations (Leita et al., 1995; Adrees et al., 2015).

Repeated application of $\mathrm{Cu}$-based fungicides in vineyards since the end of the 19th century has led to a significant increase in the total concentration of $\mathrm{Cu}$ in many viticultural soils (Magalhães et al., 1985; Brun et al., 1998; Besnard et al., 2001; Arias et al., 2004; Casali et al., 2008; Mackie et al., 2012). Since Cu is scarcely mobile in soils, it commonly remains concentrated in surface soil horizons, decreasing its concentration along the soil profile (Magalhães et al., 1985; Kabata-Pendias, 2010). However, several agricultural practices such as tillage may contribute to the presence of $\mathrm{Cu}$ in deeper layers. In practice, the presence of $\mathrm{Cu}$ in the surface layers of soil is not expected to induce phytotoxicity in mature grapevines, whose root systems extend deeply in the soil (Anne and Dupuis, 1953). In contrast, young vines have much shallower root systems, and may therefore be affected by high surface soil $\mathrm{Cu}$ concentrations (Conradie, 2004), which can lead to phytotoxicity events in vine nurseries or in recently replanted vineyards (Giovannini, 1997; Conradie, 2004; Melo et al., 2008).

Although $\mathrm{Cu}$ availability in the soil depends on factors such as soil texture, $\mathrm{pH}$, redox potential and organic matter content (Fageria et al., 2002), it has been observed that $\mathrm{Cu}$ first accumulates in the roots in some plant species (Brun et al., 2001), reducing root growth in terms of dry biomass, length, as well as branch number (Lequeux et al., 2010). Furthermore, $\mathrm{Cu}$ can induce root cuticle damage (Sheldon and Menzies, 2005) and root cracks (Michaud et al., 2008), which may decrease water and nutrient absorption capacity and thereby alter tissue nutrient levels and ultimately affect plant growth (Kopittke et al., 2009). Plant exposure to high $\mathrm{Cu}$ concentrations and its potential translocation and accumulation in shoots may lead to disrupted plant development, changes in nutrient contents, decreased chlorophyll levels in leaves, and photosynthesis inhibition (Yruela, 2005, 2009; Kabata-Pendias, 2010). Other negative effects include delayed flowering and fruiting (Brun et al., 2003; Jin et al., 2015), reduction in plant survival (Brun et al., 2003), and $\mathrm{Cu}$ translocation to grapes and wines (Vystavna et al., 2014; Sun et al., 2018). This can be harmful to the health of consumers, especially if other elements such as $\mathrm{Fe}, \mathrm{Zn}, \mathrm{Ni}, \mathrm{Pb}$, and Sc are present (Araya et al., 2003; Turnlund et al., 2004; Naughton and Petróczi, 2008). However, since plant species influence rhizosphere conditions, and consequently the availability of elements as well as their uptake (Bonfante and Genre, 2010), increased $\mathrm{Cu}$ concentrations in the soil do not necessarily lead to an increase of this element in plant tissues/organs.

Besides its effects on plants, high $\mathrm{Cu}$ concentrations are also toxic to soil organisms. Copper accumulation in soil can severely decrease total microbial biomass as well as the functional diversity of the soil microbial community, reducing decomposition rates of organic matter and impairing specific pathways of nutrient cycling (Kandeler et al., 1996; FernándezCalviño et al., 2010; Mackie et al., 2012, 2013). However, some soil microorganisms, including arbuscular mycorrhizal fungi (AMF), have developed adaptive mechanisms for their survival and growth in environments with high $\mathrm{Cu}$ concentrations (reviewed in Ferrol et al., 2009).

Arbuscular mycorrhizal fungi are obligate symbionts that colonize more than $80 \%$ of land plants (Schüßler et al., 2001). The symbiotic association is based on the exchange of nutrients between fungal partners and plants, where AMF provide the host plant with water and nutrients that would otherwise be inaccessible, and plants provide AMF with photosynthetic products (Smith and Read, 2008). In addition to an improved nutritional supply, mycorrhizal symbiosis confers numerous advantages to the plant, including increased growth and productivity and enhanced tolerance to various biotic and abiotic stresses (e.g., Pozo and Azcón-Aguilar, 2007; Smith and Read, 2008; Porcel et al., 2012; Maya and Matsubara, 2013; Augé et al., 2015). Mycorrhizal fungi can also have an important role in alleviating metal toxicity in plants (Carvalho et al., 2006; Hildebrandt et al., 2007; Ferrol et al., 2009; Ambrosini et al., 2015; Jin et al., 2015). In particular, some AMF isolates have been reported to decrease $\mathrm{Cu}$ bioavailability in contaminated soils by excreting glomalin related proteins, a type of glycoproteins, or by storing $\mathrm{Cu}$ in cellular compartments with reduced metabolism, including spores and vesicles (reviewed in Ferrol et al., 2009). Moreover, the ability of AMF species to mitigate the stress caused by high soil $\mathrm{Cu}$ contents in plants have been attributed to a promotion on the absorption of water and nutrients, particularly P, through the roots (Soares and Siqueira, 2008; Andrade et al., 2010). The enhancement of plant antioxidant enzyme activities by AMF and the consequent decrease of oxidative damage to lipids also contributes to better plant survival in Cu-contaminated soils (Merlos et al., 2016).

In grapevines, the effect of plant inoculation with AMF in soils with high $\mathrm{Cu}$ concentration varies greatly depending on the species, as seen in Ambrosini et al. (2015). In this work, the authors tested the effects of six different AMF species on young $1103 \mathrm{P}$ grapevine rootstock plants and observed that although all AMF species induced an accumulation of $\mathrm{Cu}$ in roots, Rhizophagus clarus and Rhizophagus irregulare inoculated plants had increased dry root biomass. Also, P levels were generally improved in shoots and roots, except in Destisculata heterogama and Acaulospora colombiana inoculated plants.

In view of the scarcity of data on the effect of AMF on young grapevine tolerance to high $\mathrm{Cu}$ concentrations, and of the importance of this issue for grapevine nurseries and for the replanting of new grapevines in old vineyards, in the present study the main objective was to study the effects of AMF inoculation in several growth, physiological and nutritional 
parameters in grapevines grown in an Arenosol artificially contaminated with $\mathrm{Cu}$.

\section{MATERIALS AND METHODS}

\section{Biological Material and Soil Characteristics}

Thirty dormant vines of Touriga Nacional $c v$. grafted onto 1103 Paulsen rootstock were obtained from a Portuguese plant nursery. Plant roots were washed with tap water and cut to $2 \mathrm{~cm}$ before being planted in $600 \mathrm{~mL}$ forest pot containers filled with autoclave-sterilized ( $40 \mathrm{~min}$ at $120^{\circ} \mathrm{C}$ in two consecutive days) substrate mixture of Sphagnum peat: perlite $(2: 1, V: V)$. The $\mathrm{pH}$ value of the substrate was corrected to 6.5 with $\mathrm{Ca}(\mathrm{CO})_{3}$. Grapevines were inoculated with $\mathrm{AMF}$ at planting time by placing the inoculum in the planting hole and in contact with the roots, as follows: 10 plants were inoculated with $10 \mathrm{~g}$ of Rhizoglomus irregulare (Błaszk., Wubet, Renker \& Buscot) Sieverd., G.A. Silva \& Oehl BEG-72 inoculum $(\approx 100$ infective propagules per gram of carrier material) provided by the Agrifood Institute of Research and Technology, IRTA (Barcelona, Spain) and 10 plants were inoculated with $20 \mathrm{~g}$ of Funneliformis mosseae (T.H. Nicolson \& Gerd.) C. Walker \& A. Schüßler inoculum ( $\approx 55$ infective propagules per gram) obtained from Symbiom company (Czech Republic). The remaining 10 plants were left as non-inoculated control plants, where $20 \mathrm{~g}$ of the carrier material (without AMF) was applied. Grapevines were kept under greenhouse conditions for three months and daily watered. One gram of slow release fertilizer based on NPK (16:8:16 + Micronutrients, Bayfolan Multi, Bayer) was applied in each container during this period.

After the three months growth period, shoot length and the number of leaves were recorded in all plants and root mycorrhizal colonization percentage was estimated in three composite samples from each treatment by the gridline intersect method (Giovannetti and Mosse, 1980) after staining them with 0.05\% trypan blue in lactic acid (Phillips and Hayman, 1970; Koske and Gemma, 1989). Plants were then transplanted to a soil that had been previously collected from the "Central Experimental Pole for the Conservation of Autochthonous Grapevine Genetic Variability-PORVID” in Pegões, Portugal. This soil had not been cultivated for the last six years, and prior to that it was planted with orange and plum trees. Before the experiment was set, the soil from Pegões was thoroughly homogenized, and soil samples were collected for chemical and biological analysis.

\section{Experimental Setup}

A total of $120 \mathrm{~kg}$ of air-dried soil (fraction $<5 \mathrm{~mm}$ ) from Pegões was split into two fractions. The first one $(60 \mathrm{~kg})$ was contaminated with $300 \mathrm{mg} \mathrm{kg}^{-1}$ of $\mathrm{Cu}$ (in the form of $\mathrm{CuSO}_{4} \cdot 5 \mathrm{H}_{2} \mathrm{O}$ ) and left for four weeks in plastic bags at room temperature in the dark. The other $60 \mathrm{~kg}$ were stored at identical conditions during the same period.

In July 2016, three months after inoculation, half of the noninoculated grapevine plants, $R$. irregulare-inoculated plants and F. mosseae-inoculated plants were transplanted to containers filled with $4 \mathrm{~kg}$ of $\mathrm{Cu}$-contaminated soil and the other half of the plants of each inoculation treatment were transplanted to containers filled with $4 \mathrm{~kg}$ of non-contaminated soil. Plants were left under open air conditions until the end of the growing season (beginning of October) and fertilized twice with an aqueous solution containing $\mathrm{NH}_{4} \mathrm{NO}_{3}, \mathrm{KNO}_{3}$ and $\mathrm{KH}_{2} \mathrm{PO}_{4}$ to ensure the contribution of $500 \mathrm{mg}$ of $\mathrm{N}$ and $\mathrm{K}$ and $50 \mathrm{mg}$ of $\mathrm{P}$.

During the growing season, plant performance was monitored by measuring the normalized difference vegetation index (NDVI), which is an important indicator of chlorophyll content in plants, and the photochemical reflectance index (PRI), a useful indicator of the physiological status of plants (Trotter et al., 2002; Filella et al., 2009). Additionally, in August, plant total leaf area was estimated following the non-destructive method of Lopes and Pinto (2005) adapted to greenhouse-grown young grapevine plants.

At the end of the growing season, three months after transplant, plants were harvested and shoot length and fresh root biomass were measured. Root and leaf samples were collected from each plant for chemical analysis and for the evaluation of mycorrhizal colonization. Furthermore, soil samples were collected from each container for chemical and biological analysis.

\section{Plant Chemical Analysis}

For leaf chemical analysis, 30 leaves were collected, washed with distilled water, dried at $40^{\circ} \mathrm{C}$ until constant weight was achieved and finely grounded. Although petiole mineral analysis is commonly used in mature grapevines to assess their nutritional state (Fallahi et al., 2005; Romero et al., 2010), the amount of petiole tissue in the young grapevines was not sufficient for nutrient analysis and therefore, the complete leaf tissue, including blades and petioles, was used.

For root analysis, roots were washed with distilled water and separated into two parts. One part was stored for posterior determination of root mycorrhizal colonization rate as described above, and the other part was cut and sonicated in distilled water in an ultrasound bath for $30 \mathrm{~min}$. Then, they were subsequently dried at $40^{\circ} \mathrm{C}$ until constant weight and finely grounded.

Elements (except $\mathrm{N}$ ) from leaf and root samples (3 grams per sample) were extracted with ultrapure concentrated $\mathrm{HCl} 3 \mathrm{M}$ after calcining at $500^{\circ} \mathrm{C}$ for $6 \mathrm{~h}$. Phosphorus was determined in this solution by visible spectrophotometry using the molybdenum blue method (EPA method 365.1. O’Dell, 1993) while $\mathrm{Ca}, \mathrm{Cu}, \mathrm{Fe}, \mathrm{K}, \mathrm{Mg}, \mathrm{Mn}, \mathrm{Na}$, and $\mathrm{Zn}$ were analyzed by flame atomic absorption spectroscopy. Total concentration of $\mathrm{N}$ was analyzed by Kjeldahl method (Póvoas and Barral, 1992).

\section{Biological and Chemical Analysis of Soils}

The number of mycorrhizal infective propagules and soil dehydrogenase activity were determined in three fresh soil samples collected from Pegões. The number of mycorrhizal infective propagules was estimated by the most probable number (MPN) technique (Porter, 1979; Powell, 1980) using leeks (Allium porrum L.) as trap plants, that grew during six months under greenhouse conditions. Then, leek roots were stained with a Trypan blue dye (Phillips and Hayman, 1970; Koske and Gemma, 1989) and the number of infective propagules in the soil was calculated using the mathematical model of Jarvis et al. (2010). Furthermore, overall microbial activity was assessed 
by analyzing dehydrogenase activity in another three fresh soil samples ( $<2 \mathrm{~mm}$ fraction), using the triphenyltetrazolium chloride method as described by Tabatabai (1994), using a solution of $0.1 \mathrm{M}$ of TRIS buffer ( $\mathrm{pH} 7.6$ ).

Further analysis, including $\mathrm{pH}$ and electric conductivity in $\mathrm{H}_{2} \mathrm{O}(1: 2.5 \mathrm{~m}: \mathrm{V})$, organic $\mathrm{C}$ by wet combustion and cation exchange capacity (CEC) by $1 \mathrm{~mol} \mathrm{~L}^{-1}$ ammonium acetate at $\mathrm{pH}$ 7 , were carried out on three other dried soil samples $(<2 \mathrm{~mm}$ fraction) (Póvoas and Barral, 1992). Nitric and ammoniacal $\mathrm{N}$ were analyzed following the methodology of Mulvaney (1996), and total concentrations of $\mathrm{Ca}, \mathrm{P}, \mathrm{Fe}, \mathrm{K}, \mathrm{Mg}, \mathrm{Na}, \mathrm{Cu}, \mathrm{Mn}$, and $\mathrm{Zn}$ were determined by atomic emission spectrometry with induced plasma and instrumental neutron activation analysis after acid digestion with $\mathrm{HClO}_{4}+\mathrm{HNO}_{3}+\mathrm{HCl}+\mathrm{HF}$ (Activation Laboratories Ltd, Canada).

Furthermore, after three months grapevine growth in this soil (contaminated or non-contaminated with $300 \mathrm{mg} \mathrm{kg}^{-1}$ of $\mathrm{Cu}$ ), soil $\mathrm{pH}$ and soil extractable concentrations of $\mathrm{Fe}, \mathrm{Cu}, \mathrm{Mn}$, and $\mathrm{Zn}$ were determined by previously extracting them in a aqueous solution of diethylenetriaminepentaacetic acid (DTPA) (0.005 mol L ${ }^{-1} \mathrm{DTPA}+0.1 \mathrm{~mol} \mathrm{~L}^{-1}$ triethanolamine $+0.01 \mathrm{~mol} \mathrm{~L}^{-1}$ calcium chloride; Lindsay and Norvell, 1978). The elements were analyzed by flame atomic absorption spectroscopy. In addition, soil dehydrogenase activity was also measured as described above.

\section{Statistical Analysis}

Statistical analyses were performed using the SPSS Statistics vs. 23 (IBM) software. All the data obtained were tested for normality and homogeneity of variance.

Vegetative growth parameters (number of leaves per plant and shoot length) and mycorrhizal colonization rates in grapevines grown for three months in the sterile substrate were analyzed by a one-way ANOVA test. Differences among groups were determined by a Tukey b post hoc test $(p \leq 0.05)$.

After grapevine transplant to the Arenosol, soil and plant parameters were analyzed by a two-way ANOVA where $\mathrm{Cu}$ contamination and Mycorrhizal inoculation treatment were considered as main factors. Differences among groups were determined by a Tukey b post hoc test $(p \leq 0.05)$. In cases where data did not have a normal distribution or homogeneous variance, Kruskall-Wallis test followed by Dunn-Bonferroni multiple pairwise comparison test $(p \leq 0.05)$ was implemented.

\section{RESULTS}

\section{Mycorrhizal Colonization and Grapevine Growth in Sterilized Substrate}

As demonstrated in Figure 1A, the three months period after inoculation in previously sterilized substrate resulted in wellestablished mycorrhizal symbiosis, with root colonization rates of 0.63 and 0.70 in $R$. irregulare- and F. mosseae-inoculated plants, respectively. Mycorrhizal colonization was also observed in non-inoculated plants, which was even higher than in the inoculated ones (0.78, Figure 1A). Regarding plant development in the aerial part, no differences were observed in shoot length and leaf number (Figures 1B,C).

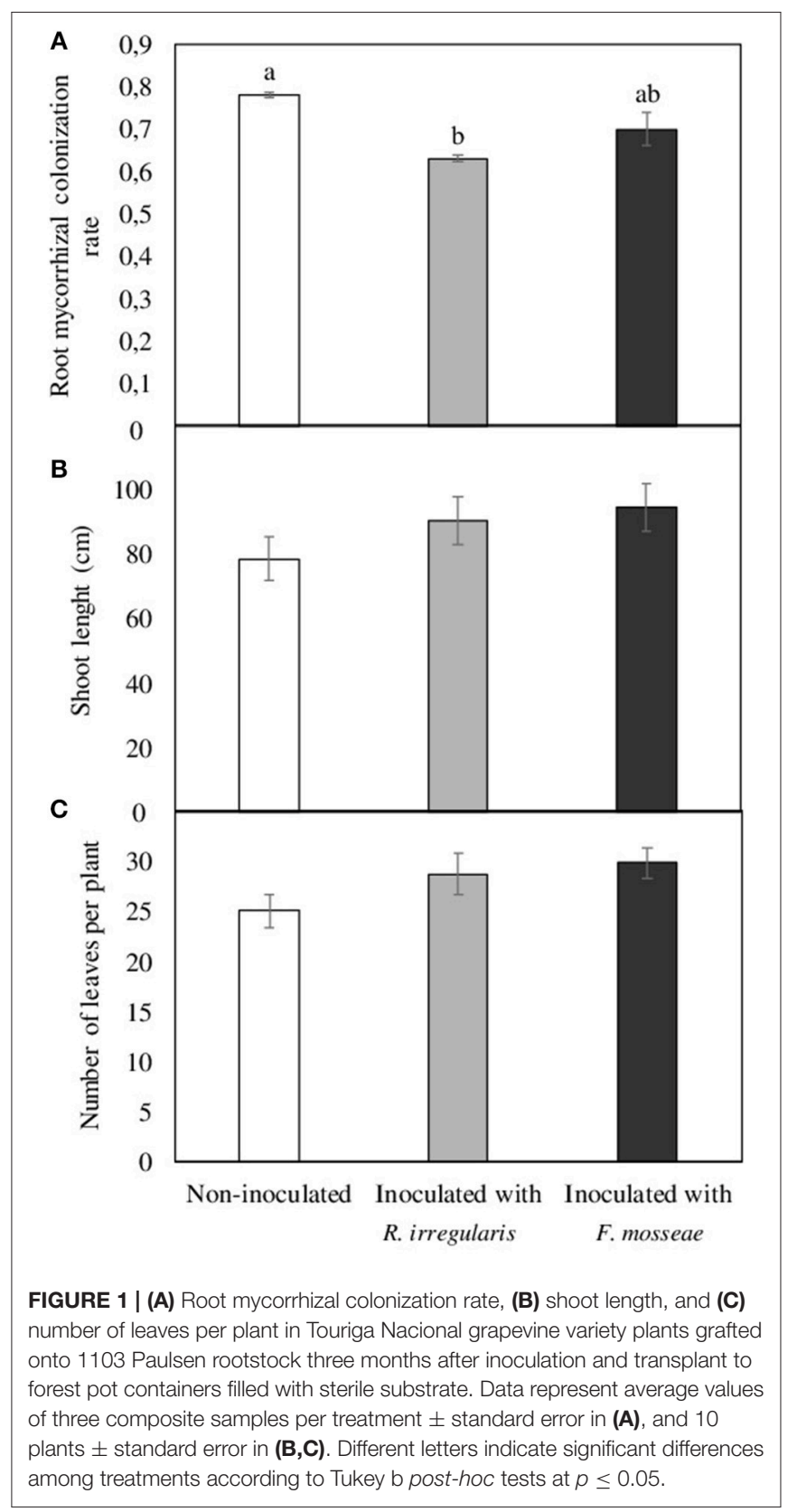

\section{Experimental Soil Characteristics}

The soil collected from Pegões and used for the experiments was an Arenosol (I. U. S. S., Working Group WRB-World Reference Base for Soil Resources, 2015) and had neutral $\mathrm{pH}$, very low fertility (as indicated by the contents of organic $\mathrm{C}$ and the two forms of mineral $\mathrm{N}$ ) as well as low electrical conductivity and CEC (Table 1). It contained 6.4 mycorrhizal infective propagules per gram of soil (Table 1).

Soil characteristics were significantly altered after the experimental period. No significant interaction was detected among the factors $\mathrm{Cu}$ contamination and Mycorrhizal inoculation treatment in $\mathrm{pH}$ or in any of the analyzed elements in the soil extractable fraction ( $\mathrm{Fe}, \mathrm{Cu}, \mathrm{Zn}$, and $\mathrm{Mn}$ - Table 2A). 
TABLE 1 | Physico-chemical and biological parameters of the soil used in the experiment.

\begin{tabular}{|c|c|}
\hline Texture & Sandy \\
\hline \multicolumn{2}{|l|}{ PHYSICO-CHEMICAL CHARACTERISTCS } \\
\hline $\mathrm{pH}\left(\mathrm{H}_{2} \mathrm{O}\right)$ & $7.0 \pm 0.03$ \\
\hline Electric conductivity $\left(\mu \mathrm{S} \mathrm{cm}^{-1}\right)$ & $73.0 \pm 2.70$ \\
\hline Cation exchange capacity $\left(\mathrm{cmol}(+) \mathrm{kg}^{-1}\right)$ & $3.06 \pm 0.170$ \\
\hline Organic C $\left(\mathrm{g} \mathrm{kg}^{-1}\right)$ & $5.7 \pm 0.213$ \\
\hline $\mathrm{N}-\mathrm{NO}_{3}\left(\mathrm{mg} \mathrm{kg}^{-1}\right)$ & $1.11 \pm 0.336$ \\
\hline $\mathrm{N}-\mathrm{NH}_{4}\left(\mathrm{mg} \mathrm{kg}^{-1}\right)$ & $1.86 \pm 0.142$ \\
\hline \multicolumn{2}{|c|}{ TOTAL NUTRIENT CONCENTRATION $\left(\mathrm{mg} \mathrm{kg}^{-1}\right)$} \\
\hline $\mathrm{Ca}$ & $933.3 \pm 27.22$ \\
\hline$P$ & $263.3 \pm 7.20$ \\
\hline $\mathrm{Fe}$ & $2400.0 \pm 216.02$ \\
\hline K & $22066.7 \pm 803.23$ \\
\hline $\mathrm{Mg}$ & $400.0 \pm 0.0$ \\
\hline $\mathrm{Na}$ & $967.3 \pm 27.21$ \\
\hline $\mathrm{Cu}$ & $26.67 \pm 1.186$ \\
\hline $\mathrm{Mn}$ & $77.00 \pm 5.735$ \\
\hline $\mathrm{Zn}$ & $14.33 \pm 1.440$ \\
\hline \multicolumn{2}{|l|}{ BIOLOGICAL CHARACTERISTCS } \\
\hline Number of mycorrhizal propagules $\left(\mathrm{g}^{-1}\right)$ & 6.4 \\
\hline Dehydrogenase activity (mg TPF.g ${ }^{-1}$ ) & $11.9 \pm 0.90$ \\
\hline
\end{tabular}

Values represent the average of 3 samples \pm standard error.

However, as expected, $\mathrm{Cu}$ contamination had a significant effect on extractable $\mathrm{Cu}$ concentration, which increased more than 41-fold, as well as on Fe and Mn, that increased 1.7 and 1.3-fold in average, respectively (Table 2B). $\mathrm{pH}$ in the contaminated soil decreased while $\mathrm{Mn}$ concentration increased. Zinc concentration was not affected by $\mathrm{Cu}$ contamination (Table 2), and the effect of mycorrhizal inoculation was not significant in any of these element concentrations (Table 2).

Copper contamination had also a significant effect on soil dehydrogenase activity (Table $\mathbf{3 A}$ ), which showed a decrease in the soil with high $\mathrm{Cu}$ concentration (Table 3B). However, the effect of mycorrhizal inoculation treatments was not significant (Table 3A).

\section{Effects of Mycorrhizal Inoculation and $\mathrm{Cu}$ Contamination on Plant Fitness}

Root mycorrhizal colonization at the end of the growing season (in October) ranged from 0.49 to 0.59 and was not affected neither by $\mathrm{Cu}$ contamination nor by the mycorrhizal inoculation treatment (Table 3).

However, although the different mycorrhizal inoculation treatments did not have a significant effect in NDVI, PRI, leaf area and shoot length in plants grown in the non-contaminated soil (Figures 2, 3), these parameters were affected by high $\mathrm{Cu}$ concentration in the soil.

In the $\mathrm{Cu}$-contaminated soil, starting in July, just two weeks after grapevine transplant, a significant decrease in NDVI index was already observed in all mycorrhizal inoculation treatments (Figure 2A). By October, this decrease was only statistically significant in F. mosseae-inoculated plants (Figure 2A).
Concerning PRI, in July only non-inoculated plants had a significant decrease due to $\mathrm{Cu}$ contamination (Figure 2B), but in October, all three inoculation treatments showed a significant decrease on this index, which was lowest in $R$. irregulare-inoculated plants (Figure 2B).

By the end of the experimental period, $\mathrm{Cu}$ contamination in the soil induced a general decrease in total leaf area and shoot length (Figures 3A,B). Total plant leaf area was reduced in 32.4 and $33.5 \%$ in $R$. irregulare- and F. mosseae- inoculated plants, respectively, while non-inoculated plants showed a decrease of only $10.3 \%$. The decrease in shoot length was similar for all three inoculation treatments, ranging from 19.6 to $24.2 \%$.

Plants grown at high soil $\mathrm{Cu}$ concentrations presented leaves with interveinal chlorosis, that in some cases (mostly in the noninoculated plants) were accompanied by dark spots (Figure 4). Those symptoms started two weeks after transplant in noninoculated plants, and later, in September, they were also observed in AMF-inoculated plants. Symptomatic leaves were mainly the youngest ones. At the end of the growing season, noninoculated plants presented $70 \%$ of symptomatic leaves, while $R$. irregulare- and F. mosseae- inoculated plants presented 51 and $59 \%$ of symptomatic leaves, respectively. Nonetheless, due to the high variability in this parameter within the same treatment, statistical differences were not significant (data not shown).

Concerning root biomass, a significant interaction was found between $\mathrm{Cu}$ contamination and Mycorrhizal inoculation treatment factors. In the non-contaminated soil, AMF inoculated plants had significantly higher root biomass than non-inoculated ones (Figure 3C). However, in the Cu-contaminated soil, these plants were the ones showing the largest decrease, 73.1 and $66.8 \%$, respectively (Figure 3C), while the non-inoculated ones kept relatively unchanged root biomass.

\section{Effects of AMF Inoculation and Cu on Plant Nutritional Status}

At the end of the growing season, after the three months experimental period, in the non-contaminated soil, nutrient concentration in roots did not differ among mycorrhizal inoculation treatments (Table 4). In leaves, only P concentration showed a significant effect of the mycorrhizal inoculation treatment, being F. mosseae-inoculated plants the ones showing the highest $\mathrm{P}$ levels, followed by non-inoculated and by $R$. irregulare- inoculated plants (Table 5).

In the contaminated soil, high levels of $\mathrm{Cu}$ led to a general increase in root $\mathrm{Cu}$, as well as in $\mathrm{Mg}$ and $\mathrm{Mn}$ concentrations, although no differences were detected among inoculation treatments. However, $R$. irregulare-inoculated plants presented an increase in root $\mathrm{Zn}, \mathrm{K}, \mathrm{Fe}$ and $\mathrm{Na}$ and a decrease in $\mathrm{Ca}$ concentrations (Table 4).

Results indicate that $\mathrm{Cu}$-contaminated soils clearly affect the leaf nutritional status of grapevines, evident as significant differences in the concentrations of key mineral elements. There were significant decreases in $\mathrm{N}, \mathrm{P}$ and $\mathrm{Fe}$ and increases in $\mathrm{Na}$ and $\mathrm{Mn}$ concentrations in leaves of plants growing in the $\mathrm{Cu}$-contaminated soil (Table 5). The decrease in $\mathrm{N}$ and $\mathrm{P}$ in 
TABLE 2 | (A) P-values of the two-way ANOVA test for the effects of the factors "Copper contamination" and "Mycorrhizal inoculation treatment" and their interaction; (B) soil $\mathrm{pH}$ and micronutrient concentration in extractable fraction of the soil after three months growth of Touriga Nacional grapevine variety plants grafted onto $1103 \mathrm{P}$ rootstock inoculated or not with $R$. irregulare or F. mosseae.

\begin{tabular}{|c|c|c|c|c|c|c|}
\hline \multicolumn{2}{|l|}{ (A) Factor } & Soil pH & $\mathrm{Fe}$ & $\mathrm{Cu}$ & Zn & Mn \\
\hline \multicolumn{2}{|l|}{ Copper contamination } & $<0.0001$ & $<0.0001$ & $<0.0001$ & 0.076 & 0.005 \\
\hline \multicolumn{2}{|c|}{ Mycorrhizal inoculation treatment } & 0.357 & 0.686 & 0.658 & 0.489 & 0.353 \\
\hline \multicolumn{2}{|l|}{ Interaction } & 0.343 & 0.573 & 0.161 & 0.390 & 0.503 \\
\hline \multirow[t]{2}{*}{ (B) Soil treatment } & Inoculation treatment & Soil pH & \multicolumn{4}{|c|}{ Micronutrient concentration in the extractable fraction $\left(\mathbf{m g ~} \mathbf{~ g g}^{-1}\right)$} \\
\hline & & & $\mathrm{Fe}$ & $\mathrm{Cu}$ & $\mathrm{Zn}$ & Mn \\
\hline \multirow[t]{3}{*}{ Non-contaminated soil } & Non-inoculated & $7.2 \pm 0.06 \mathrm{a}$ & $12.12 \pm 0.733 b$ & $2.68 \pm 0.119 b$ & $1.79 \pm 0.240 \mathrm{a}$ & $1.96 \pm 0.128 \mathrm{a}$ \\
\hline & Inoculated with $R$. irregulare & $7.3 \pm 0.09 a$ & $15.71 \pm 1.875 \mathrm{ab}$ & $3.03 \pm 0.201 b$ & $1.89 \pm 0.435 a$ & $1.84 \pm 0.109 a$ \\
\hline & Inoculated with F. mosseae & $7.3 \pm 0.04 \mathrm{a}$ & $12.49 \pm 1.045 b$ & $2.46 \pm 0.191 b$ & $1.63 \pm 0.150 \mathrm{a}$ & $1.91 \pm 0.157 \mathrm{a}$ \\
\hline \multirow[t]{3}{*}{ Cu-contaminated soil } & Non-inoculated & $6.8 \pm 0.07 b$ & $22.44 \pm 1.944 \mathrm{a}$ & $128.37 \pm 4.910 \mathrm{a}$ & $2.68 \pm 0.338 a$ & $2.75 \pm 0.321 a$ \\
\hline & Inoculated with $R$. irregulare & $6.9 \pm 0.04 b$ & $22.51 \pm 2.698 \mathrm{a}$ & $125.16 \pm 10.760 \mathrm{a}$ & $1.89 \pm 0.165 a$ & $2.39 \pm 0.205 a$ \\
\hline & Inoculated with F. mosseae & $6.7 \pm 0.04 b$ & $23.49 \pm 2.267 \mathrm{a}$ & $131.99 \pm 2.560 \mathrm{a}$ & $2.19 \pm 0.286 \mathrm{a}$ & $2.20 \pm 0.152 \mathrm{a}$ \\
\hline
\end{tabular}

Data represent average values $(n=5) \pm$ standard error. Different letters indicate significant differences according to Tukey b a posteriori test. Significant effect: $p$-value $\leq 0.05$.

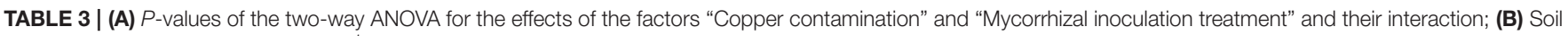

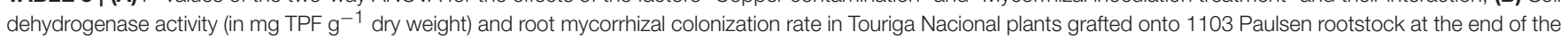
growing season.

\begin{tabular}{|c|c|c|c|c|}
\hline (A) Factor & \multicolumn{2}{|c|}{ Soil dehydrogenase activity } & \multicolumn{2}{|c|}{ Root mycorrhizal colonization rate } \\
\hline Copper contamination & \multicolumn{2}{|c|}{$<0.0001$} & \multicolumn{2}{|c|}{0.744} \\
\hline Mycorrhizal inoculation treatment & \multicolumn{2}{|c|}{0.287} & \multicolumn{2}{|c|}{0.575} \\
\hline Interaction & \multicolumn{2}{|c|}{0.567} & \multicolumn{2}{|c|}{0.919} \\
\hline \multirow[t]{2}{*}{ (B) Inoculation treatment } & \multicolumn{2}{|c|}{ Soil dehydrogenase activity } & \multicolumn{2}{|c|}{ Root mycorrhizal colonization rate } \\
\hline & Non-contaminated soil & Cu-contaminated soil & Non-contaminated soil & Cu-contaminated soil \\
\hline Non-inoculated & $13.80 \pm 1.386 \mathrm{a}$ & $0.67 \pm 0.086 b$ & $0.54 \pm 0.069 a$ & $0.49 \pm 0.070 \mathrm{a}$ \\
\hline Inoculated with $R$. irregulare & $12.34 \pm 0.812 \mathrm{a}$ & $0.49 \pm 0.069 b$ & $0.55 \pm 0.034 a$ & $0.59 \pm 0.026 a$ \\
\hline Inoculated with F. mosseae & $13.64 \pm 1.689 a$ & $0.50 \pm 0.069 b$ & $0.51 \pm 0.059 \mathrm{a}$ & $0.52 \pm 0.053 \mathrm{a}$ \\
\hline
\end{tabular}

Data represent average values $(n=5) \pm$ standard error. Different letters indicate significant differences among treatments according to Tukey $b$ a posteriori tests at $p$-value $\leq 0.05$.

leaves was greater in F. mosseae-inoculated plants than in noninoculated or in $R$. irregulare- inoculated plants: with 31.2 vs. $16.3 \%$ and $11.7 \%$, decrease respectively in $\mathrm{N}$ concentration, and 73 vs. $56.8 \%$ and $37.0 \%$ in $\mathrm{P}$ concentrations (Table 5). Although $\mathrm{N}$ and $\mathrm{P}$ concentrations were most altered in F. mosseaeinoculated plants grown in contaminated soil, these were able to sustain leaf Fe levels relatively unchanged. In contrast, a Fe decrease of nearly $30 \%$ was observed in non-inoculated and $R$. irregulare- inoculated plants (Table 5).

The largest alteration in response to soil $\mathrm{Cu}$ contamination was observed in leaf Mn concentrations, with the highest increase in the levels of this element in non-inoculated and F. mosseaeinoculated plants (5.3-fold and 3.5-fold, respectively). These increases were significantly higher than those observed in $R$. irregulare- inoculated plants, which had a 2.1-fold increase (Table 5). Sodium concentration in leaves was also significantly affected by $\mathrm{Cu}$ contamination, particularly in non-inoculated and in F. mosseae- inoculated plants, with a 1.6- and a 1.4- fold increase, while $R$. irregulare-inoculated plants were again the ones showing the least alteration (Table 5). No changes were observed in $\mathrm{K}, \mathrm{Ca}, \mathrm{Mg}, \mathrm{Cu}$, and $\mathrm{Zn}$ concentrations in response to $\mathrm{Cu}$ contamination or to mycorrhizal inoculation treatments.

\section{DISCUSSION}

Plant inoculation with beneficial soil microorganisms such as AMF is increasingly being used in agricultural ecosystems as a way to enhance plant stress tolerance, productivity and sustainability (Gianinazzi et al., 2010; Verbruggen et al., 2013). However, the successful establishment of AMF inoculants in the field depends on several factors, such as soil physicochemical and biological characteristics, including the resident mycorrhizal community in the soil (Köhl et al., 2016). For this reason, to ensure the establishment of $R$. irregulare and F. mosseae inoculants in Touriga Nacional grapevines, one-year 


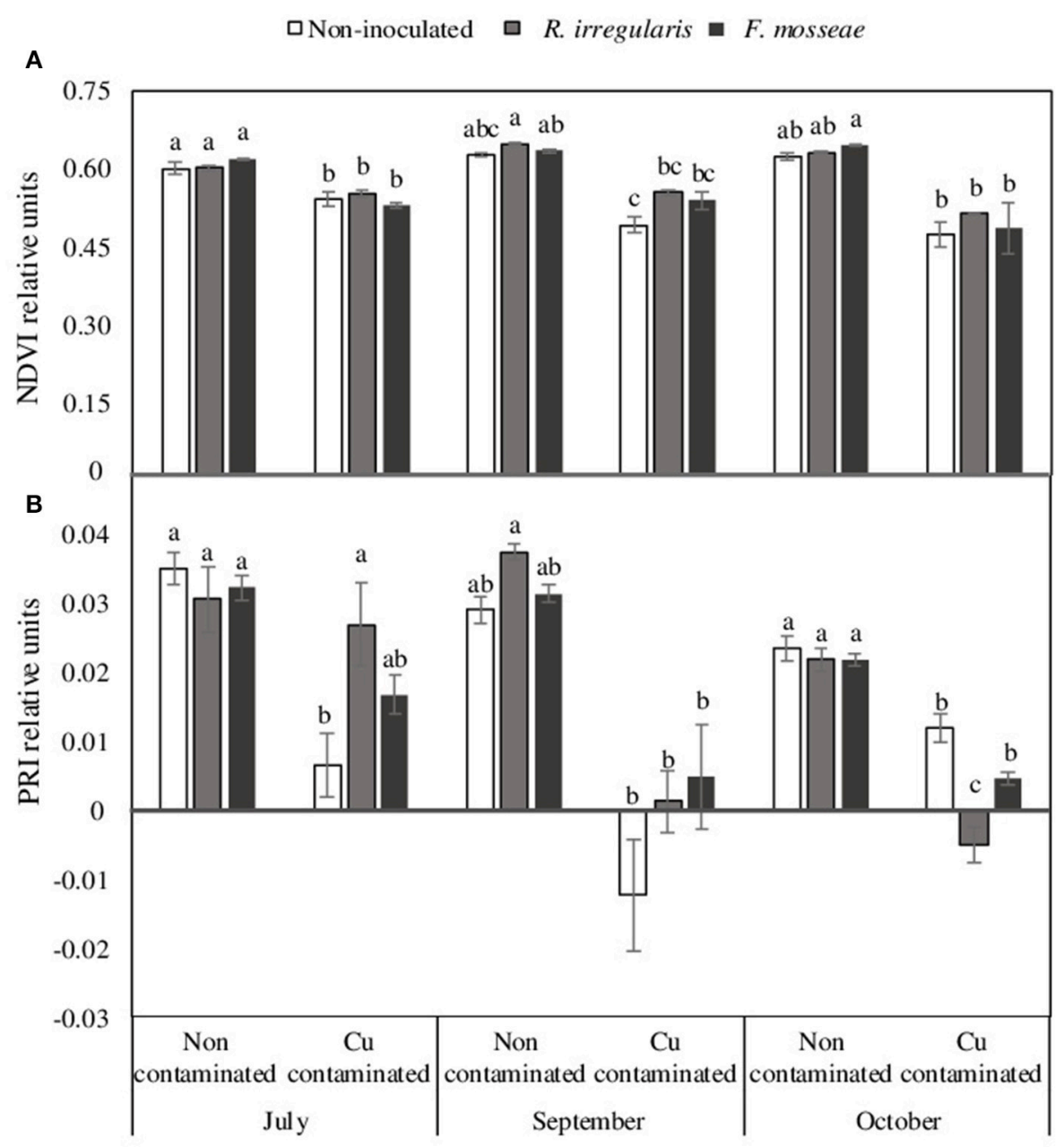

FIGURE 2 | (A) Normalized difference vegetation index, NDVI and (B) Photochemical reflectance index, PRI, data of Touriga Nacional grapevine variety plants grafted onto 1103 Paulsen rootstock growing in Cu-contaminated or non-contaminated soil at different time points during the growing season. Bars indicate the average of five plants per treatment \pm standard error. Different letters indicate significant differences at each month (July, September or October) according to Tukey b or Dunn-Bonferroni tests at $p \leq 0.05$.

old plants obtained from a nursery were pre-inoculated in a sterile substrate. After three months growth in this substrate, root AMF colonization could be observed in all plants, including the non-inoculated ones, indicating that indigenous AMF from the nursery remained and developed in the roots even though these had been previously cut to $2 \mathrm{~cm}$ and washed. Unexpectedly, these plants had the highest colonization rates (Figure 1), which may indicate the occurrence of competition within roots of $R$. irregulare- or $F$. mosseae-inoculated plants between the indigenous fungus/fungi and the inoculated AMF, leading to lower colonization rates. Although under natural conditions multiple occupancy could be more beneficial to the host plant (i.e. complementary function of the AMF species) than a single colonization by a single AMF isolate (Jansa et al., 2008; Wagg et al., 2011), competitive interactions have been observed among AMF species (Hepper et al., 1988; Cano and Bago, 2005; Verbruggen et al., 2013; Gijsbert et al., 2015). In fact, mycorrhizal fungi can compete intraradically for host-derived carbon (Thonar et al., 2014), which normally results in reduced root colonization rates (Wilson and Trinick, 1983; Wilson, 1984; Pearson et al., 1994; Cano and Bago, 2005; Engelmoer et al., 2014; Lu et al., 2015). Moreover, additional competitive interactions seem to have taken place when grapevine plants were transplanted to the Arenosol, as mycorrhizal colonization rate was approximately 0.50 in the new roots grown in the non-contaminated Arenosol (Table 2). In this case, competition in the intraradical space would have been between the AMF already colonizing grapevine roots and the resident AMF from the soil, which were present in a concentration of approximately 6.4 mycorrhizal propagules per g. In a parallel study conducted with the same plant genotypes and inoculation treatments but using a previously sterilized soil from the same location, root colonization rates were significantly higher after three months, around 0.80 in all three inoculation treatment plants (non-inoculated, $R$. irregulare- and F. mosseaeinoculated plants) (Nogales et al., 2017). Being soil sterilization 


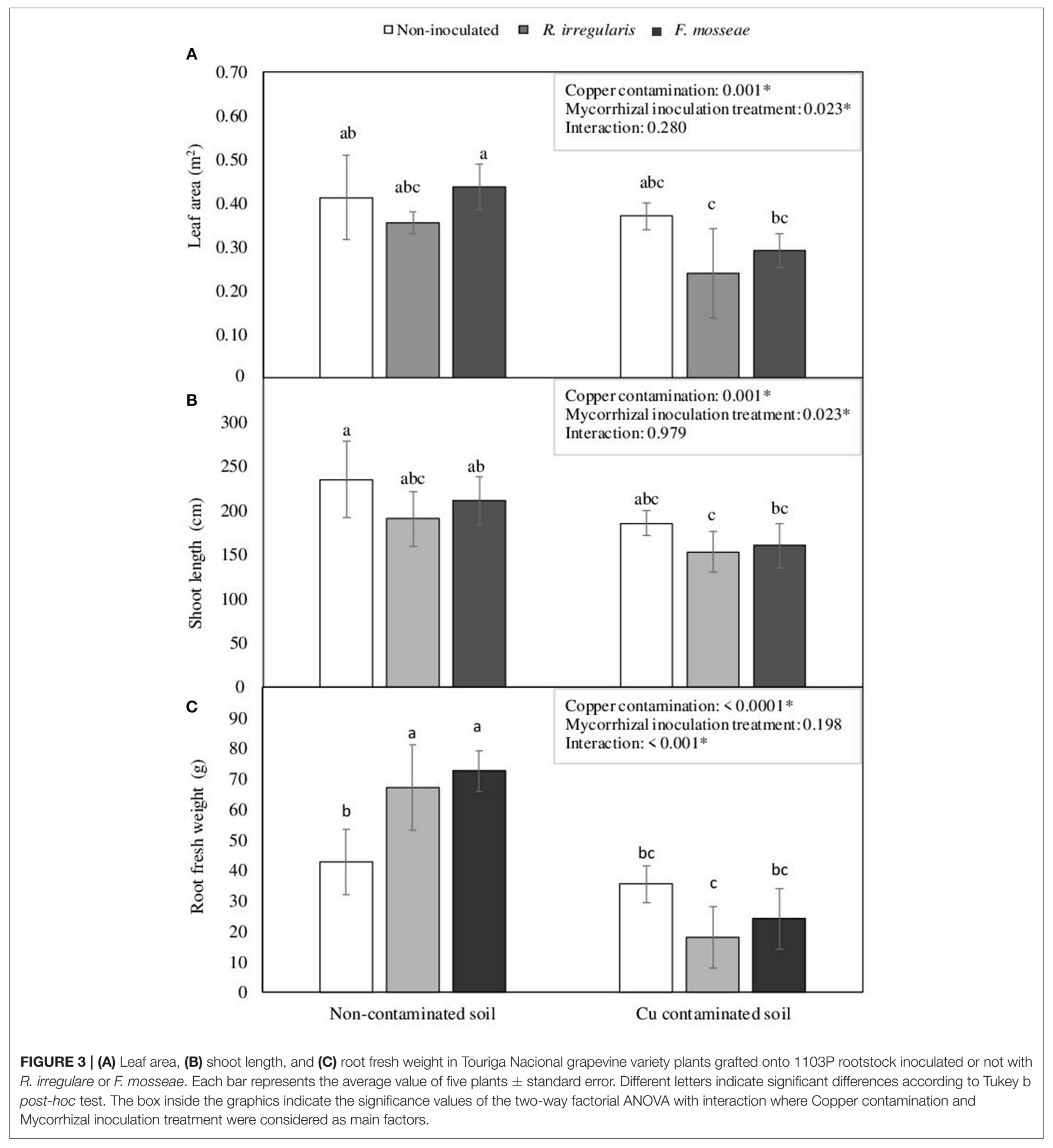

the unique difference, it seems likely that the reason for the lower colonization rates in the present non-sterile soil is the presence of indigenous AMF.

Regardless of the competition in the intraradical space, plants still benefited from the AMF inoculation, as even if colonization rates were similar in inoculated and non-inoculated plants growing in the non-contaminated Arenosol, root biomass was significantly higher in $R$. irregulare- and F. mosseae-inoculated plants (Figure 3C). Furthermore, P concentration in leaves was also highest in F. mosseae-inoculated plants, although $R$. irregulare-inoculated plants were in this case the ones showing the lowest content (Table 3). In fact, even though mycorrhizal 

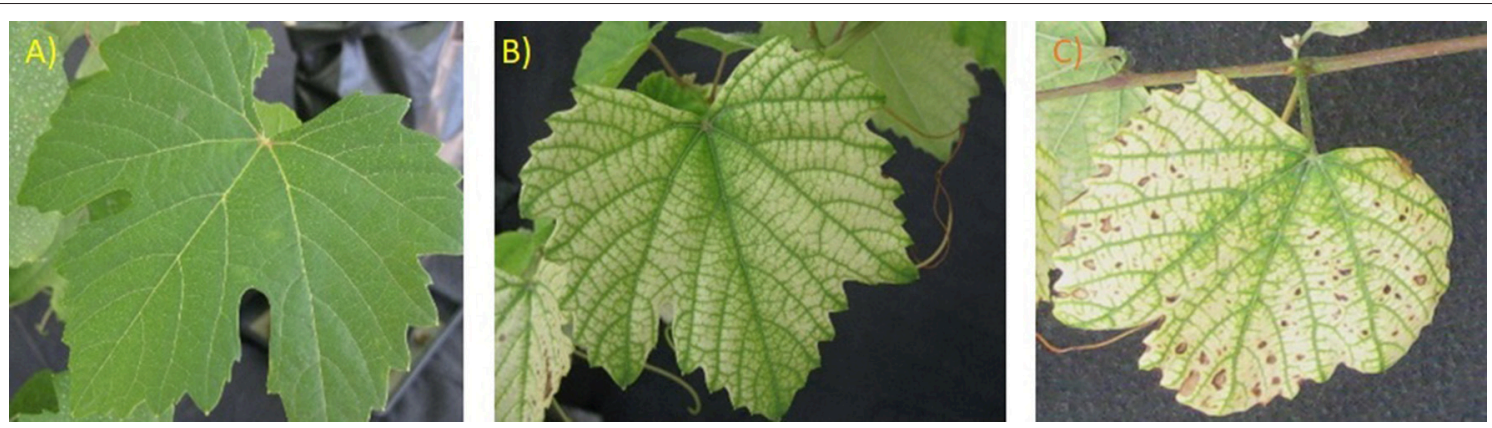

FIGURE 4 | (A) Non-symptomatic leaf of a grapevine plant grown in the non-contaminated Arenosol. (B) Interveinal chlorosis symptoms in a grapevine plant growing in the $\mathrm{Cu}$-contaminated Arenosol. (C) Chlorosis and dark spots in a grapevine plant growing in the Cu-contaminated Arenosol.

inoculation commonly increases root and leaf $\mathrm{P}$ concentration in grapevines (Schreiner, 2005b; Khalil, 2013), this greatly (although not exclusively) depends on the identity of the fungal partner(s) (Biricolti et al., 1997; Schreiner, 2005a). Apart from P, the rest of the macro- and micronutrients were not affected by the inoculation treatments in the non-contaminated soil. In grapevines, data relying on the role of AMF in the uptake of macro- and micronutrients others than $\mathrm{P}$ and $\mathrm{N}$ are relatively scarce and sometimes contradictory, which might also be due to the fact that nutritional responses in mycorrhizal grapevines depend greatly on the scion, on the rootstock and on the inoculated AMF (Trouvelot et al., 2015). Therefore, the data from the present study suggest that in this soil, the introduction of $F$. mosseae would be the best option to improve plant $\mathrm{P}$ nutrition and root biomass in Touriga Nacional plants grafted onto 1103 Paulsen rootstock.

However, it is important to note that changes in the host's environment, especially abiotic and biotic stresses, can influence greatly the outcome of the symbiosis (Pearson et al., 1994; Hoeksema et al., 2010; Verbruggen et al., 2013), including high soil $\mathrm{Cu}$ concentration (Meier et al., 2015). Hence, the evaluation of the effect of high soil $\mathrm{Cu}$ concentration in mycorrhizal grapevines, especially in the extractable fraction (considered as available to the organisms), is extremely important for viticulture. In the present study, the concentration of $\mathrm{Cu}$ added into the Arenosol attempted to simulate the highest $\mathrm{Cu}$ contents observed in Portuguese vineyards (Magalhães et al., 1985; Dias, 1995; Dias and Soveral-Dias, 1997).

Excess copper had various effects on the plants as well as on the soil. Soil dehydrogenase activity, which is an indicator of overall microbial activity and soil quality (Watts et al., 2010; Liang et al., 2014), decreased drastically from 11.9 to 0.67 TTF. $\mathrm{g}^{-1}$ three months after $\mathrm{Cu}$ addition (Tables 1, 3). However, it needs to be considered that soil dehydrogenase activity measurements can vary greatly depending on the method used and depending on soil properties, especially pH (Januszek et al., 2015). Although $\mathrm{Cu}$ can be toxic for soil microorganisms at high concentrations, it is yet unclear whether the soil dehydrogenase activity decrease was due to $\mathrm{Cu}$ toxicity, to soil $\mathrm{pH}$ decrease (Table 2), which commonly reduces its activity (Januszek et al., 2015), or to a combination of both factors.
On the other hand, root mycorrhizal colonization rate was not affected by high $\mathrm{Cu}$ concentration, evident as no differences found in colonization rates between the plants grown in $\mathrm{Cu}$-contaminated and non-contaminated soils. There is some evidence in the literature of decreased mycorrhizal root colonization in plants grown in metal contaminated soils (Karagiannidis and Nikolaou, 2000; Klauberg-Filho et al., 2005; Zhang et al., 2012; Ferrol et al., 2016), while other studies also reveal no changes on this parameter related to soil pollution (Cicatelli et al., 2010).

With $\mathrm{Cu}$ addition to the soil, grapevine plants showed a general decrease in NDVI and PRI, as well as in leaf area, shoot length and root biomass, which agrees with other studies in young grapevines grown in $\mathrm{Cu}$-contaminated soils, that also showed reduced root and shoot growth, leaf chlorosis and $\mathrm{Cu}$ accumulation in roots (Toselli et al., 2009). However, after three months growth in such soil conditions, differences were observed among plants of the three inoculation treatments, being $F$. mosseae-inoculated plants the ones showing the largest decrease in NDVI and leaf area, and R. irregulare-inoculated plants the ones showing the largest decrease in PRI and root biomass (Figures 2, 3). Non-inoculated plants were the less affected by $\mathrm{Cu}$ contamination, especially in terms of root growth (Figure 3C).

As observed for vegetative parameters, the effect of AMF inoculation on plant nutrition under high soil $\mathrm{Cu}$ concentrations was different from the one observed under non-contaminated soil conditions. This agrees with Meier et al. (2015), who found that the effect of different mycorrhizal treatments on the levels of shoot nutrients depended on soil $\mathrm{Cu}$ concentration. Ambrosini et al. (2015) observed that although mycorrhizal inoculation of grapevines in soils with high soil $\mathrm{Cu}$ concentrations induced root accumulation of this element, translocation to leaves depended on the inoculated species, and was only observed in plants inoculated with Rhizoglomus clarus and Acaulospora morrowiae. In Touriga Nacional plants grafted onto 1103 Paulsen rootstock, $\mathrm{Cu}$ contamination led to an accumulation of this element in roots, but no translocation to leaves was observed. Besides, roots and shoots from all three mycorrhizal inoculation treatments presented similar $\mathrm{Cu}$ contents (Tables 4, 5).

At high concentrations, $\mathrm{Cu}$ commonly interacts with other elements. These interactions can be antagonistic or synergistic, 







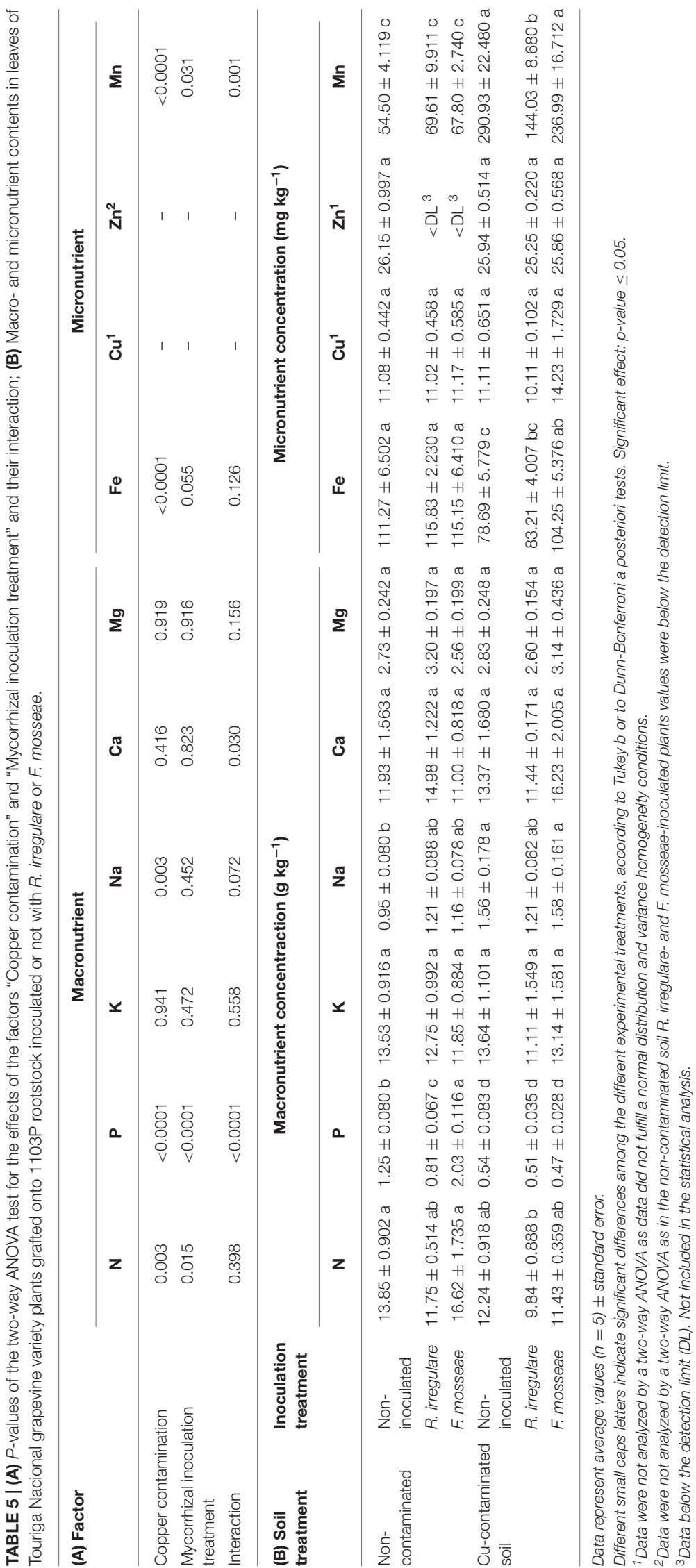


as $\mathrm{Cu}$ can inhibit or stimulate the absorption of other elements in plants, leading to imbalanced reactions that may cause a chemical stress in plants and a consequent growth decrease (KabataPendias, 2010). In the present study, $\mathrm{Cu}$ addition in the soil induced an increase in the bioavailability of $\mathrm{Mn}$ and $\mathrm{Fe}$ in the soil, and a general increase in root $\mathrm{Cu}, \mathrm{Mn}$ and $\mathrm{Mg}$ contents (Tables 2, 4). Thus, the altered concentration of these elements in roots might have contributed to the root growth decrease observed in plants grown in the contaminated soil. Moreover, plants inoculated with $R$. irregulare showed as well altered levels of other nutrients in roots such as an increase in $\mathrm{Zn}, \mathrm{Fe}, \mathrm{K}$ and $\mathrm{Na}$, and a decrease in $\mathrm{Ca}$ concentration (Table 4), which may have contributed to the higher decrease in root biomass observed in these plants.

Even though $\mathrm{Cu}$ contamination induced a general increase in the concentration of these elements in roots, only Mn was translocated from the soil to the leaves, while $\mathrm{Cu}$ itself remained accumulated in roots. Although $\mathrm{Mn}$ uptake is metabolically controlled, when present at high available soil concentrations, its uptake may also be passive and can be rapidly translocated within plants (Kabata-Pendias, 2010). This could explain the large $\mathrm{Mn}$ increase found in roots and leaves in grapevines, which was particularly high in non-inoculated and F. mosseaeinoculated plant leaves (Table 5). Manganese shows antagonistic interactions with $\mathrm{Fe}$, and therefore, when $\mathrm{Mn}$ is in excess, it competes with Fe for binding sites in enzymes and can interfere with its transport from roots to shoots (Srivastava and Gupta, 1996), leading to $\mathrm{Fe}$ deficiency. In general, an appropriate level of both elements is needed for a healthy plant growth (Fe:Mn ratio should be between 1.5 and 2.5), as both elements are interrelated in their metabolic functions (Kabata-Pendias, 2010). Thus, an increase of Mn leads to low Fe:Mn ratios and subsequent symptoms of Fe deficiency and Mn toxicity. Those are characterized by chlorosis and brown spots on leaves, where Mn is concentrated (Kabata-Pendias, 2010). These symptoms were similar to the ones observed in our plants, especially in the noninoculated ones (Figure 4). In fact, the lowest Fe:Mn ratio was observed in these ones (0.27), followed by F. mosseae- inoculated (0.44) and $R$. irregulare-inoculated plants (0.58).

Excess $\mathrm{Cu}$ in the soil can also interfere directly in the absorption and translocation of $\mathrm{Fe}$ into the plant, resulting in a decrease of chlorophyll content (Kabata-Pendias, 2010) that appears as yellowing or chlorosis in the interveinal areas of the emerging leaves and that later expands until the entire leaf turns yellow and finally white (Treeby et al., 2004). It seems therefore that the interveinal chlorosis observed in young leaves of Touriga Nacional plants grown in the contaminated soil (Figure 4) and the decrease in leaf Fe concentration (Table 5) can be due to a negative interaction of leaf Fe content with high concentrations of $\mathrm{Cu}$ in roots and with $\mathrm{Mn}$ in roots and leaves. The largest decreases in Fe content in leaves were observed in non-inoculated and $R$. irregulare-inoculated plants (29 and $28 \%$, respectively, vs. $9 \%$ in F. mosseae-inoculated plants). In fact, according to Romero et al. (2014), Fe levels would be below the optimal levels recommended for grapevines in noninoculated and an in R. irregulare-inoculated plants (below $99 \mathrm{mg}$ $\mathrm{kg}^{-1}$ ).
On the other hand, the decrease in leaf $\mathrm{P}$ and $\mathrm{N}$ concentration does not seem to be related to a decrease in both nutrient uptakes, as both element concentrations in roots were not affected by $\mathrm{Cu}$ contamination. This is in contrast to the study of Melo et al. (2008) who observed that as soil $\mathrm{Cu}$ concentration increased in an Udorthent soil (with low organic matter content) $\mathrm{N}$ and $\mathrm{P}$ concentrations decreased in 1103 Paulsen plant roots $\left(R^{2}=\right.$ 0.52 and 0.38 , respectively). However, in leaves, they also found a linear decrease in $\mathrm{N}$ and $\mathrm{P}$ contents as $\mathrm{Cu}$ concentration increased in the soil (Melo et al., 2008), while Toselli et al. (2009) observed a decrease in leaf $\mathrm{P}$ concentration but not a decrease in $\mathrm{N}$ in young potted grapevine $c v$. Sangiovese plants grafted onto SO4. In Touriga Nacional plants, the observed decrease in leaf $\mathrm{P}$ concentration could be related to an antagonistic interaction between $\mathrm{Mn}$ and $\mathrm{P}$, as reductions in plant $\mathrm{P}$ with increasing $\mathrm{Mn}$, especially at very high Mn concentrations, have also been observed in other plant species (Gunes et al., 1998; Sarkar et al., 2004).

Copper and $\mathrm{Zn}$ interactions are also commonly observed because both metals seem to be absorbed by the same mechanism and therefore each may competitively inhibit root absorption of the other (Kabata-Pendias, 2010). However, in the present study, no antagonism was observed between both elements, as at high soil $\mathrm{Cu}$ concentrations the concentrations of both elements in roots increased and remained unchanged in leaves (Tables 4, 5). This is in agreement to Toselli et al. (2009), who also found that high soil $\mathrm{Cu}$ concentrations did not alter leaf $\mathrm{Cu}$ and $\mathrm{Zn}$ contents in young potted vines $c v$. Sangiovese, although they reported an antagonistic interaction among both elements in roots.

Several studies suggest that the ability of AMF species to mitigate the stress caused by soil $\mathrm{Cu}$ contamination in plants is due to a promotion in the absorption of water and nutrients (Soares and Siqueira, 2008; Andrade et al., 2010), specially P (Ambrosini et al., 2015). Nonetheless, in the present study, no clear relation was observed between a better plant nutrition and a better tolerance of Touriga Nacional plants to high $\mathrm{Cu}$ soil concentrations in terms of growth. Indeed, $R$. irregulareinoculated plants were the ones sustaining better the decrease in $\mathrm{P}$ and the increases in $\mathrm{Mn}$ and $\mathrm{Na}$ contents in leaves, but they were, together with $F$. mosseae-inoculated plants, the ones showing the largest decrease in total leaf areas and root biomass. By contrast, non-inoculated plants were the ones sustaining better their growth in the contaminated soil, but they were the ones showing the highest increase in $\mathrm{Mn}$ and $\mathrm{Na}$ in leaves.

The better growth response of non-inoculated plants to the high $\mathrm{Cu}$ level in the available soil fraction when compared to the AMF inoculated plants could be related to the fact that both $R$. irregulare and F. mosseae isolates used in this study were highly infective and fast growing (both isolates are sold commercially). Consequently, their carbon demand to the plant might be higher than the one of the indigenous species from the nursery and from the Arenosol, and in such stressful environment where plant's carbon availability is commonly reduced, this might result in a growth decrease. In fact, AMF may express different symbiotic lifestyles depending on environmental factors and stress conditions, on host genotypes or on their physiological status. Based on these factors, AMF may establish mutualistic 
symbioses, commensalistic symbioses (providing no benefit to the plant), or parasitic symbioses (resulting in a negative growth response, as observed when the costs of the symbiosis exceed the nutritional benefits to the host) (Johnson and Graham, 2013). It is clear therefore, that soil chemical composition is an important factor to take into account when selecting the most appropriate AMF to inoculate grapevines.

\section{CONCLUSIONS}

Although grapevine plants benefited from the inoculation with $R$. irregulare and F. mosseae during development in an Arenosol with normal $\mathrm{Cu}$ concentration, inoculation with those AMF revealed to be non-efficient or even detrimental to grapevine growth in the same soil with high $\mathrm{Cu}$ concentration in the available fraction. In this soil, the native AMF present in the non-inoculated plants, proceeding from the plant nursery and/or the field, were more efficient in sustaining shoot and root growth. However, considering plant nutritional status, $R$. irregulare-inoculated plants were the ones better avoiding Mn increase in leaves, and F. mosseae-inoculated plants were the ones that better sustained leaf Fe levels. As grapevine nutritional status is crucial for obtaining a good wine quality, these parameters need to be considered when deciding about the suitability of field AMF inoculation for a particular grapevine genotype.

It remains clear therefore that soil environment, especially the occurrence of soil contaminants such as $\mathrm{Cu}$, and the presence of native AMF are crucial factors to consider before grapevine mycorrhizal inoculation in vineyards. Also importantly,

\section{REFERENCES}

Adrees, M., Ali, S., Rizwan, M., Ibrahim, M., Abbas, F., Farid, M., et al. (2015). The effect of excess copper on growth and physiology of important food crops: a review. Environ. Sci. Pollut. Res. 22, 8148-8162. doi: 10.1007/s11356-015-4496-5

Ambrosini, V. G., Gerent, V. J., Ludiana, C., Rosa, C. R., da, Ademar, A. F. P., Jos,é, C. J., et al. (2015). Arbuscular mycorrhizal fungi on young vines in copper contaminated soil. Brazilian J. Microbiol. 46, 1045-1052. doi: 10.1590/S1517-838246420140622

Andrade, S. A. L., Silveira, A. P. D., and Mazzafera, P. (2010). Arbuscular mycorrhiza alters metal uptake and the physiological response of Coffea arabica seedlings to increasing $\mathrm{Zn}$ and $\mathrm{Cu}$ concentrations in soil. Sci. Total Environ. 408, 5381-5391. doi: 10.1016/j.scitotenv.2010.07.064

Anne, P., and Dupuis, M. (1953). Toxicité du cuivre a l'egard de quelques plantes cultivées. C.R. Acad. Agric. Fr. 39, 58-61.

Araya, M., Olivares, M., Pizarro, F., Gonzalez, M., Speisky, H., and Uauy, R. (2003). Copper exposure and potential biomarkers of copper metabolism. BioMetals 16, 199-204. doi: 10.1023/A:1020723117584

Arias, M., Lopez, E., Fernandez, D., and Soto, B. (2004). Copper distribution and dynamics in acid vineyard soils treated with copper-based fungicides. Soil Sci. 169, 796-805. doi: 10.1097/01.ss.0000148739.82992.59

Augé, R. M., Toler, H. D., and Saxton, A. M. (2015). Arbuscular mycorrhizal symbiosis alters stomatal conductance of host plants more under drought than under amply watered conditions: a meta-analysis. Mycorrhiza 25, 13-24. doi: 10.1007/s00572-014-0585-4

Besnard, E., Chenu, C., and Robert, M. (2001). Influence of organic amendments on copper distribution among particle-size and density inoculation procedures should deserve special attention due to potential competition between AMF species/isolates in the soil, as here demonstrated.

\section{AUTHOR CONTRIBUTIONS}

AN, MMA, HSP, CL, and WV conceived and designed research. $\mathrm{AN}$ and ES conducted experiments. AN, ES, DA, and GV analyzed and interpreted the results. AN wrote the manuscript and all authors read and approved the manuscript.

\section{FUNDING}

Authors are thankful to the Fundação para a Ciência e a Tecnologia (FCT/MCTES) for the funding received through the project MYCOVITIS (PTDC/AGR-PRO/0676/2014) and the grant SFRH/BPD/108358/2015. The research work was developed on LEAF Unit financed by FCT -UID/AGR/04129/2013.

\section{ACKNOWLEDGMENTS}

Authors would like as well to thank Prof. Antero Martins and PROVID for providing vineyard soil, Dr. Cinta Calvet and Dr. Amèlia Camprubí (Agrifood Institute of Research and Technology-IRTA, Barcelona, Spain) for kindly providing $R$. irregulare inoculum, Ricardo Egipto for his help in plant maintenance, Patricia Vidigal for her insightful comments and ideas on the experiment and Paula Silva for her help with plant and soil chemical analysis. fractions in Champagne vineyard soils. Environ. Pollut. 112, 329-337. doi: 10.1016/S0269-7491(00)00151-2

Biricolti, S., Ferrini, F., Rinaldelli, E., Tamantini, I., and Vignozzi, N. (1997). VAM fungi and soil lime content influence rootstock growth and nutrient content. Am. J. Enol. Vitic. 48, 93-99

Bonfante, P., and Genre, A. (2010). Mechanisms underlying beneficial plantfungus interactions in mycorrhizal symbiosis. Nat. Commun. 1, 1-11. doi: $10.1038 /$ ncomms 1046

Brun, L., Maillet, J., Hinsinger, P., and Pépin, M. (2001). Evaluation of copper availability to plants in copper-contaminated vineyard soils. Environ. Pollut. 111, 293-302. doi: 10.1016/S0269-7491(00)00067-1

Brun, L., Maillet, J., Richarte, J., Herrmann, P., and Remy, J. (1998). Relationships between extractable copper, soil properties and copper uptake by wild plants in vineyard soils. Environ. Pollut. 102, 151-161. doi: 10.1016/S0269-7491(98)00120-1

Brun, L. A., Le Corff, J., and Maillet, J. (2003). Effects of elevated soil copper on phenology, growth and reproduction of five ruderal plant species. Environ. Pollut. 122, 361-368. doi: 10.1016/S0269-7491(02)00312-3

Cano, C., and Bago, A. (2005). Competition and substrate colonization strategies of three polyxenically grown arbuscular mycorrhizal fungi. Mycologia 97, 1201-1214. doi: 10.1080/15572536.2006.11832730

Carvalho, L. M., Caçador, I., and Martins-Loução, M. A. (2006). Arbuscular mycorrhizal fungi enhance root cadmium and copper accumulation in the roots of the salt marsh plant Aster tripolium L. Plant Soil 285, 161-169. doi: 10.1007/s11104-006-9001-y

Casali, C. A., Moterle, D. F., dos Santos Rheinheime, D., Brunetto, G., Corcini, A. L. M., Kaminski, J., et al. (2008). Formas e dessorção de cobre em solos cultivados com videira na Serra Gaúcha do Rio Grande do Sul. 
Rev. Bras. Ciência do Solo 32, 1479-1487. doi: 10.1590/S0100-068320080004 00012

Cicatelli, A., Lingua, G., Todeschini, V., Biondi, S., Torrigiani, P., and Castiglione, S. (2010). Arbuscular mycorrhizal fungi restore normal growth in a white poplar clone grown on heavy metal-contaminated soil, and this is associated with upregulation of foliar metallothionein and polyamine biosynthetic gene expression. Ann. Bot.106, 791-802. doi: 10.1093/aob/mcq170

Conradie, K. (2004). Copper Levels in South African Nursery Soils: Possible Effects on the Propagation of Grapevines - Wineland Magazine. Available online at: http://www.wineland.co.za/copper-levels-in-south-african-nurserysoils-possible-effects-on-the-propagation-of-grapevines/ (Accessed July 27, 2018).

Dias, R. M. S. (1995). Estudo da Contaminação com Cobre dos Solos de Vinha das Regiões do Dão e do Ribatejo e Oeste. Master's thesis, Instituto Superior de Agronomia- Universidade técnica de Lisboa, Portugal.

Dias, R. S., and Soveral-Dias, J. C. (1997). Levels of copper, zinc and manganese in the vineyard soils of Dão wine region - Portugal. Mod. Agric. Environ. 71, 469-477. doi: 10.1007/978-94-011-5418-5 39

Engelmoer, D. J. P., Behm, J. E., and Toby Kiers, E. (2014). Intense competition between arbuscular mycorrhizal mutualists in an in vitro root microbiome negatively affects total fungal abundance. Mol. Ecol. 23, 1584-1593. doi: 10.1111/mec.12451

Fageria, N. K., Baligar, V. C., and Clark, R. B. (2002). Micronutrients in crop production. Adv. Agron. 77, 185-268. doi: 10.1016/S0065-2113(02)77015-6

Fallahi, E., Shafii, B., Stark, J. C., Fallahi, B., and Hafez, S. L. (2005). Influence of wine grape cultivars on growth and leaf blade and petiole mineral nutrients. Horttechnology 15, 825-830. doi: 10.21273/HORTTECH.15.4.0825

Fernández-Calviño, D., Soler-Rovira, P., Polo, A., Díaz-Raviña, M., Arias-Estévez, M., and Plaza, C. (2010). Enzyme activities in vineyard soils long-term treated with copper-based fungicides. Soil Biol. Biochem. 42, 2119-2127. doi: 10.1016/j.soilbio.2010.08.007

Ferrol, N., González-Guerrero, M., Valderas, A., Benabdellah, K., and Azcón-Aguilar, C. (2009). Survival strategies of arbuscular mycorrhizal fungi in Cu-polluted environments. Phytochem. Rev. 8, 551-559. doi: 10.1007/s11101-009-9133-9

Ferrol, N., Tamayo, E., and Vargas, P. (2016). The heavy metal paradox in arbuscular mycorrhizas: from mechanisms to biotechnological applications. J. Exp. B. 67, 6253-6265. doi: 10.1093/jxb/erw403

Filella, I., Porcar-Castell, A., Munné-Bosch, S., Bäck, J., Garbulsky, M. F., and Peñuelas, J. (2009). PRI assessment of long-term changes in carotenoids/chlorophyll ratio and short-term changes in de-epoxidation state of the xanthophyll cycle. Int. J. Remote Sens. 30, 4443-4455. doi: 10.1080/01431160802575661

Gianinazzi, S., Gollotte, A., Binet, M.-N., van Tuinen, D., Redecker, D., and Wipf, D. (2010). Agroecology: the key role of arbuscular mycorrhizas in ecosystem services. Mycorrhiza 20, 519-530. doi: 10.1007/s00572-010-0333-3

Gijsbert, D., Werner, A., and Kiers, E. T. (2015). Partner selection in the mycorrhizal mutualism. New Phytol. 205, 1437-1442. doi: 10.1111/nph.13113

Giovannetti, M., and Mosse, B. (1980). An evaluation of techniques for measuring vesicular arbuscular mycorrhizal infection in roots. New Phytol. 84, 489-500. doi: 10.1111/j.1469-8137.1980.tb04556.x

Giovannini, E. (1997). Toxidez por combre em vinhedos. Pesqui. Agropecu. Gauch. 3, 115-117.

Gunes, A., Alpaslan, M., and Inal, A. (1998). Critical nutrient concentrations and antagonistic and synergistic relationships among the nutrients of NFT-grown young tomato plants. J. Plant Nutr. 21, 2035-2047. doi: 10.1080/01904169809365542

Hepper, C. M., Azcon-Aguilar, C., Rosendahl, S., and Sen, R. (1988). Competition between three species of Glomus used as spatially separated introduced and indigenous mycorrhizal inocula for leek (Allium porrum L.). New Phytol. 110, 207-215. doi: 10.1111/j.1469-8137.1988.tb00254.x

Hildebrandt, U., Regvar, M., and Bothe, H. (2007). Arbuscular mycorrhiza and heavy metal tolerance. Phytochemistry 68, 139-146. doi: 10.1016/j.phytochem.2006.09.023

Hoeksema, J. D., Chaudhary, V. B., Gehring, C. A., Johnson, N. C., Karst, J., Koide, R. T., et al. (2010). A meta-analysis of context-dependency in plant response to inoculation with mycorrhizal fungi. Ecol. Lett. 13, 394-407. doi: 10.1111/j.1461-0248.2009.01430.x
I. U. S. S., Working Group WRB - World Reference Base for Soil Resources (2015). International Soil Classification System for Naming Soils and Creating Legends for Soil Maps.World soil resources reports $\mathrm{N}^{\circ} 103$, FAO, Rome.

Jansa, J., Smith, F. A., and Smith, S. E. (2008). Are there benefits of simultaneous root colonization by different arbuscular mycorrhizal fungi? New Phytol. 177, 779-789. doi: 10.1111/j.1469-8137.2007.02294.x

Januszek, K., Błonska, E., Długa, J., and Socha, J. (2015). Dehydrogenase activity of forest soils depends on the assay used. Int. Agrophys. 29, 47-59. doi: 10.1515/intag-2015-0009

Jarvis, B., Wilrich, C., and Wilrich, P. T. (2010). Reconsideration of the derivation of Most Probable Numbers, their standard deviations, confidence bounds and rarity values. J. Appl. Microbiol. 109, 1660-1667. doi: 10.1111/j.1365-2672.2010.04792.x

Jin, Z., Li, J., and Li, Y. (2015). Interactive effects of arbuscular mycorrhizal fungi and copper stress on flowering phenology and reproduction of Elsholtzia splendens. PLoS ONE 10:e0145793. doi: 10.1371/journal.pone.0145793

Johnson, N. C., and Graham, J. H. (2013). The continuum concept remains a useful framework for studying mycorrhizal functioning. Plant Soil 363, 411-419. doi: 10.1007/s11104-012-1406-1

Kabata-Pendias, A. (2010). Trace Elements in Soils and Plants, 4th Edn. Boca Raton, FL: CRC Press; Taylor \& Francis Group.

Kandeler, F., Kampichler, C., and Horak, O. (1996). Influence of heavy metals on the functional diversity of soil microbial communities. Biol. Fertil. Soils 23, 299-306. doi: 10.1007/BF00335958

Karagiannidis, N., and Nikolaou, N. (2000). Influence of arbuscular mycorrhizae on heavy metal ( $\mathrm{Pb}$ and $\mathrm{Cd})$ uptake, growth, and chemical composition of Vitis vinifera L. (cv. Razaki). Am J. Eno.l Vitic. 51, 269-275. Available online at: http:// www.ajevonline.org/content/51/3/269.

Khalil, H. A. (2013). Influence of vesicular-arbuscular mycorrhizal fungi (Glomus spp.) on the response of grapevines rootstocks to salt stress. Asian J. Crop Sci. 5, 393-404. doi: 10.3923/ajcs.2013.393.404

Klauberg-Filho, O., Siqueira, J. O., Moreira, F. M. S., de Sousa Soares, C. R. F., and Silva, S. (2005). "Ecologia, função e potencial de aplicação de fungos micorrízicos arbusculares em condições de excesso de metais pesados," in Tópicos em Ciência do Solo, eds P. Vidal-Torrado, L. R. F. Alleoni, M. Cooper, A. P. Silva, and E. J. Cardoso (UFV - Viçosa, Sociedade Brasileira de Ciência do Solo), 85-144.

Köhl, L., Lukasiewicz, C. E., and van der Heijden, M. G. A. (2016). Establishment and effectiveness of inoculated arbuscular mycorrhizal fungi in agricultural soils. Plant. Cell Environ. 39, 136-146. doi: 10.1111/pce.12600

Kopittke, P. M., Asher, C. J., Blamey, F. P. C., and Menzies, N. W. (2009). Toxic effects of $\mathrm{Cu}^{2+}$ on growth, nutrition, root morphology, and distribution of $\mathrm{Cu}$ in roots of Sabi grass. Sci. Total Environ. 407, 4616-4621. doi: 10.1016/j.scitotenv.2009.04.041

Koske, R. E., and Gemma, J. N. (1989). A modified procedure for staining roots to detect VA mycorrhizas. Mycol. Res. 92, 486-488. doi: 10.1016/S0953-7562(89)80195-9

Leita, L., De Nobili, M., Muhlbachova, G., Mondini, C., Marchiol, L., and Zerbi, G. (1995). Bioavailability and effects of heavy metals on soil microbial biomass survival during laboratory incubation. Biol. Fertil. Soils 19, 103-108. doi: 10.1007/BF00336144

Lequeux, H., Hermans, C., Lutts, S., and Verbruggen, N. (2010). Response to copper excess in Arabidopsis thaliana: Impact on the root system architecture, hormone distribution, lignin accumulation and mineral profile. Plant Physiol. Biochem. 48, 673-682. doi: 10.1016/j.plaphy.2010.05.005

Liang, Q., Chen, H., Gong, Y., Yang, H., Fan, M., and Kuzyakov, Y. (2014). Effects of 15 years of manure and mineral fertilizers on enzyme activities in particle-size fractions in a North China Plain soil. Eur. J. Soil Biol. 60, 112-119. doi: 10.1016/j.ejsobi.2013.11.009

Lindsay, W. L., and Norvell, W. A. (1978). Development of a DTPA soil test for zinc, iron, manganese, and copper. Soil Sci. Soc. Am. J. 42:421. doi: 10.2136/sssaj1978.03615995004200030009x

Lopes, C. M., and Pinto, P. A. (2005). Easy and accurate estimation of grapevine leaf area with simple mathematical models. Vitis 44, 55-61.

Lu, N., Zhou, X., Cui, M., Yu, M., Zhou, J., Qin, Y., et al. (2015). Colonization with arbuscular mycorrhizal fungi promotes the growth of Morus alba L. seedlings under greenhouse conditions. Forests 6, 734-747. doi: 10.3390/f60 30734 
Mackie, K. A., Müller, T., and Kandeler, E. (2012). Remediation of copper in vineyards - A mini review. Environ. Pollut. 167, 16-26. doi: 10.1016/j.envpol.2012.03.023

Mackie, K. A., Müller, T., Zikeli, S., and Kandeler, E. (2013). Long-term copper application in an organic vineyard modifies spatial distribution of soil microorganisms. Soil Biol. Biochem. 65, 245-253. doi: 10.1016/j.soilbio.2013.06.003

Magalhães, M. J., Sequeira, E. M., and Lucas, M. D. (1985). Copper and zinc in vineyards of Central Portugal. Water. Air. Soil Pollut. 26, 1-17. doi: 10.1007/BF00299485

Marschner, H. (1995). Mineral Nutrition of Higher Plants. 2nd Edn. London, UK; Waltham, MA; San Diego, CA: Academic Press.

Maya, M. A., and Matsubara, Y. (2013). Influence of arbuscular mycorrhiza on the growth and antioxidative activity in cyclamen under heat stress. Mycorrhiza 23, 381-390. doi: 10.1007/s00572-013-0477-z

Meier, S., Cornejo, P., Cartes, P., Borie, F., Medina, J., and Azcón, R. (2015). Interactive effect between $\mathrm{Cu}$-adapted arbuscular mycorrhizal fungi and biotreated agrowaste residue to improve the nutritional status of Oenothera picensis growing in Cu-polluted soils. J. Plant Nutr. Soil Sci. 178, 126-135. doi: 10.1002/jpln.201400092

Melo, G. W., Brunetto, G., Junior, A. S., Kaminski, J., and Furlanetto, V. (2008). Matéria seca e acumulação de nutrientes em videiras jovens cultivadas em solos com diferentes níveis de cobre. Rev. Bras. Agrociência Pelotas 14, 72-76. Available online at: https://ainfo.cnptia.embrapa.br/digital/bitstream/ item/56986/1/MELO-RevBrasAgrocienc-v14n4p72-2008.pdf

Merlos, M. A., Zitka, O., Vojtech, A., Azcón-Aguilar, C., and Ferrol, N. (2016). The arbuscular mycorrhizal fungus Rhizophagus irregularis differentially regulates the copper response of two maize cultivars differing in copper tolerance. Plant Sci. 253, 68-76. doi: 10.1016/j.plantsci.2016.09.010

Michaud, A. M., Chappellaz, C., and Hinsinger, P. (2008). Copper phytotoxicity affects root elongation and iron nutrition in durum wheat (Triticum turgidum durum L.). Plant Soil 310, 151-165. doi: 10.1007/s11104-008-9642-0

Miotto, A., Ceretta, C. A., Brunetto, G., Nicoloso, F. T., Girotto, E., Farias, J. G., et al. (2014). Copper uptake, accumulation and physiological changes in adult grapevines in response to excess copper in soil. Plant Soil 374, 593-610. doi: 10.1007/s11104-013-1886-7

Mulvaney, R. L. (1996). "Nitrogen - Inorganic forms" in Method of Soil Analysis: Chemical Methods. Part 3, ed. D. L. Sparks (Madison: Soil Science Society of America), 1123-1184.

Naughton, D., and Petróczi, A. (2008). Heavy metal ions in wines: Metaanalysis of target hazard quotients reveal health risks. Chem. Cent. J. 3, $1-7$. doi: 10.1186/1752-153X-2-22

Nogales, A., Ribeiro, H., Véstia, J., Peixe, A., Gonçalves, E., Viegas, W., et al. (2017). "Calorespirometry as a Tool to Study Mycorrhiza Induced Heat Stress Tolerance," Book of abstracts of the $1^{\circ}$ Congresso Luso-Brasileiro de Horticultura. Lisbon.

O'Dell, J. W. (1993). Method 365.1, Revision 2.0: Determination of Phosphorus by Semi-automated Colorimetry.

Pearson, J. N., Abbott, L. K., and Jasper, D. A. (1994). Phosphorus, soluble carbohydrates and the competition between two arbuscular mycorrhizal fungi colonizing subterranean clover. New Phytol. 127, 101-106. doi: 10.1111/j.1469-8137.1994.tb04263.x

Phillips, J. M., and Hayman, D. S. (1970). Improved procedures for clearing roots and staining parasitic and vesicular-arbuscular mycorrhizal fungi for rapid assessment of infection. Trans. Br. Mycol. Soc. 55, 158-IN18. doi: 10.1016/S0007-1536(70)80110-3

Porcel, R., Aroca, R., and Ruiz-Lozano, J. M. (2012). Salinity stress alleviation using arbuscular mycorrhizal fungi. A review. Agron. Sustain. Dev. 32, 181-200. doi: 10.1007/s13593-011-0029-x

Porter, W. (1979). The "most probable number" method for enumerating infective propagules of vesicular arbuscular mycorrhizal fungi in soil. Aust. J. Soil Res. 17:515.

Póvoas, I., and Barral, M. F. (1992). Métodos de Análise de Solos. Comunicações do Instituto de Investigação Científica Tropical. Lisboa, Portugal: Instituto de Investigação Científica Tropical: Serie Ciências Agrárias.

Powell, C. L. (1980). Mycorrhizal infectivity of eroded soils. Soil Biol. Biochem. 12, 247-250. doi: 10.1016/0038-0717(80)90069-3

Pozo, M. J., and Azcón-Aguilar, C. (2007). Unraveling mycorrhiza-induced resistance. Curr. Opin. Plant Biol. 10, 393-398. doi: 10.1016/j.pbi.2007.05.004
Raven, J. A., Evans, M. C. W., and Korb, R. E. (1999). The role of trace metals in photosynthetic electron transport in $\mathrm{O}_{2}$-evolving organisms. Photosynth. Res. 60, 111-150. doi: 10.1023/A:1006282714942

Romero, I., Benito, A., Dominguez, N., Garcia-Escudero, E., and Martin, I. (2014). Leaf blade and petiole nutritional diagnosis for Vitis vinifera L. cv. "Tempranillo" by deviation from optimum percentage method. Spanish J. Agric. Res. 12, 206-214. doi: 10.5424/sjar/2014121-4308

Romero, I., García-Escudero, E., and Martín, I. (2010). Effects of leaf position on blade and petiole mineral nutrient concentration of Tempranillo grapevine (Vitis vinifera L.). Am. J. Enol. Vitic. 61, 544-5550. doi: 10.5344/ajev.2010.09091

Sarkar, D., Pandey, S., Sud, K., and Chanemougasoundharam, A. (2004). In vitro characterization of manganese toxicity in relation to phosphorus nutrition in potato (Solanum tuberosum L.). Plant Sci. 167, 977-986. doi: 10.1016/j.plantsci.2004.05.022

Schreiner, R. P. (2005a). "Mycorrhizas and mineral acquisition in grapevines1 soil environment and vine mineral nutrition," in Proceedings of the Soil Environment and Vine Mineral Nutrition Symposium, eds J. Christensen and D. Smart (Davis, CA: American Society for Enology and Viticulture), 49-60.

Schreiner, R. P. (2005b). Spatial and temporal variation of roots, arbuscular mycorrhizal fungi, and plant and soil nutrients in a mature Pinot Noir (Vitis vinifera L.) vineyard in Oregon, USA. Plant Soil 276, 219-234. doi: 10.1007/s11104-005-4895-0

Schüßler, A., Schwarzott, D., and Walker, C. (2001). A new fungal phylum, the Glomeromycota: phylogeny and evolution. Mycol. Res. 105, 1413-1421. doi: $10.1017 /$ S0953756201005196

Sheldon, A. R., and Menzies, N. W. (2005). The effect of copper toxicity on the growth and root morphology of Rhodes grass (Chloris gayana Knuth.) in resin buffered solution culture. Plant Soil 278, 341-349. doi: $10.1007 /$ s11104-005-8815-3

Smith, S. E., and Read, D. J. (2008). Mycorrhizal Symbiosis. New York, NY: Academic Press.

Soares, C. R. F. S., and Siqueira, J. O. (2008). Mycorrhiza and phosphate protection of tropical grass species against heavy metal toxicity in multi-contaminated soil. Biol. Fertil. Soils 44, 833-841. doi: 10.1007/s00374-007-0265-Z

Srivastava, P. C., and Gupta, U. C. (1996). Trace Elements in Crop Production. Lebanon: Science Publishers, Inc.

Sun, X., Ma, T., Yu, J., Huang, W., Fang, Y., and Zhan, J. (2018). Investigation of the copper contents in vineyard soil, grape must and wine and the relationship among them in the Huaizhuo Basin Region, China: a preliminary study. Food Chem. 241, 40-50. doi: 10.1016/j.foodchem.2017.08.074

Tabatabai, M. A. (1994). "Soil enzymes" in Methods of Soil Analysis. Part 2. Microbiological and Biochemical Properties, eds. R. W. Weaver and J. S. Angle, and P. S. Bottomley (Madison, WI: Soil Science Society of America), 775-833.

Thonar, C., Frossard, E., Šmilauer, P., and Jansa, J. (2014). Competition and facilitation in synthetic communities of arbuscular mycorrhizal fungi. Mol. Ecol. 23, 733-746. doi: 10.1111/mec.12625

Toselli, M., Baldi, E., Marcolini, G., Malaguti, D., Quartieri, M., Sorrenti, G., et al. (2009). Response of potted grapevines to increasing soil copper concentration. Aust. J. Grape Wine Res. 15, 85-92. doi: 10.1111/j.1755-0238.2008.00040.x

Treeby, M. T., Goldspink, B. H., and Nicholas, P. (2004). "Vine nutrition," in Grape Production Series No. 2. Soil, Irrigation and Nutrition, eds. B. P. Nicholas (Adelaide, SA: South Australian Research and Development Institute), 173-197.

Trotter, G. M., Whitehead, D., and Pinkney, E. J. (2002). The photochemical re ectance index as a measure of photosynthetic light use eYciency for plants with varying foliar nitrogen contents. Int. J. Remote Sens. 23, 1207-1212. doi: 10.1080/01431160110106096

Trouvelot, S., Bonneau, L., Redecker, D., Tuinen, V., Adrian, M., Wipf, D., et al. (2015). Arbuscular mycorrhiza symbiosis in viticulture: a review. Agron. Sustain. Dev. 35, 1449-1467. doi: 10.1007/s13593-0150329-7

Turnlund, J. R., Jacob, R. A., Keen, C. L., Strain, J. J., Kelley, D. S., Domek, J. M., et al. (2004). Long-term high copper intake: Effects on indexes of copper status, antioxidant status, and immune function in young men. Am. J. Clin. Nutr. 79, 1037-1044. doi: 10.1093/ajcn/79.6.1037

Verbruggen, E., van der Heijden, M. G. A., Rillig, M. C., and Kiers, E. T. (2013). Mycorrhizal fungal establishment in agricultural soils : 
Factors determining inoculation success. New Phytol. 197, 1104-1109. doi: 10.1111/j.1469-8137.2012.04348.x

Vystavna, Y., Rushenko, L., Diadin, D., Klymenko, O., and Mykola, K. (2014). Trace metals in wine and vineyard environment in southern Ukraine. Food Chem. 146, 339-344. doi: 10.1016/j.foodchem.2013. 09.091

Wagg, C., Jansa, J., Schmid, B., and van der Heijden, M. G. A. (2011). Belowground biodiversity effects of plant symbionts support aboveground productivity. Ecol. Lett. 14, 1001-1009. doi: 10.1111/j.1461-0248.2011. 01666.x

Watts, D. B., Torbert, H. A., Feng, Y., and Prior, S. A. (2010). Soil microbial community dynamics as influenced by composted dairy manure, soil properties, and landscape position. Soil Sci. 175, 474-486. doi: 10.1097/SS.0b013e3181f7964f

Wilson, J. M. (1984). Competition for infection between vesiculararbuscular mycorrhizal fungi. New Phytol. 97, 427-435. doi: 10.1111/j.1469-8137.1984.tb03608.x

Wilson, J. M., and Trinick, M. J. (1983). Infection development and interactions between vesicular-arbuscular mycorrhizal fungi. New Phytol. 93, 543-553. doi: 10.1111/j.1469-8137.1983.tb02705.x
Yruela, I. (2005). Copper in plats. Braz. J. Plant Physiol. 17, 145-156. doi: 10.1590/S1677-04202005000100012

Yruela, I. (2009). Copper in plants: acquisition, transport and interactions. Funct. Plant Biol. 36:409. doi: 10.1071/FP08288

Zhang, X. H., Wang, Y. S., and Lin, A. J. (2012). Effects of arbuscular mycorrhizal colonization on the growth of upland rice (Oryza sativa L.) in soil experimentally contaminated with $\mathrm{Cu}$ and $\mathrm{Pb}$. Clinic Toxicol. S3:1-5. doi: 10.4172/2161-0495.S3-003

Conflict of Interest Statement: The authors declare that the research was conducted in the absence of any commercial or financial relationships that could be construed as a potential conflict of interest.

Copyright (c) 2019 Nogales, Santos, Abreu, Arán, Victorino, Pereira, Lopes and Viegas. This is an open-access article distributed under the terms of the Creative Commons Attribution License (CC BY). The use, distribution or reproduction in other forums is permitted, provided the original author(s) and the copyright owner(s) are credited and that the original publication in this journal is cited, in accordance with accepted academic practice. No use, distribution or reproduction is permitted which does not comply with these terms. 